\title{
Transitional and small aquatic cave habitats diversification based on protist assemblages in the Veternica cave (Medvednica Mt., Croatia)
}

\author{
Najla Bakovićc ${ }^{1,2,3}$, Renata Matoničkin Kepčija ${ }^{4}$, Ferry J. Siemensma ${ }^{5}$ \\ I Croatian Biospeleological Society, Demetrova 1, 10000 Zagreb, Croatia 2 ADIPA - Society for Research and \\ Conservation of Croatian Natural Diversity, Orehovečki ogranak 37, 10040 Zagreb, Croatia 3 DVOKUT- \\ ECRO Ltd, Trnjanska 37, 10000 Zagreb, Croatia 4 University of Zagreb, Faculty of Science, Department of \\ Biology, Rooseveltov $\operatorname{trg}$ 6, 10000 Zagreb, Croatia 5 Julianaweg 10, 1241 VW Kortenhoef, Netherlands \\ Corresponding author: Najla Baković (najla.bakovic@gmail.com)
}

Academic editor:RosauraMayén-Estrada|Received 15November2021|Accepted 17January2022|Published25January 2022

http://zoobank.org/8EE87027-21D3-4C36-B27B-616602E9522F

Citation: Baković N, Matoničkin Kepčija R, Siemensma FJ (2022) Transitional and small aquatic cave habitats diversification based on protist assemblages in the Veternica cave (Medvednica Mt., Croatia). Subterranean Biology 42 : 43-60. https://doi.org/10.3897/subtbiol.42.78037

\begin{abstract}
Protists in caves are scarcely researched. Most cave studies address the diversity of protists, but very little is known about their habitats and spatio-temporal dynamics. The aim of this study was to investigate the diversity and abundance of protists in the Veternica cave in the Medvednica mountain in Croatia on hygropetric and sinter and clay pools during six months. During this study, 47 protists taxa were distinguished belonging to the groups of heterotrophic flagellates, ciliates, heliozoans, stramenopiles and testate and naked amoebae. The highest taxon richness was found at the sinter pool site richest in bats guano (36 taxa). Most diverse were testate amoebae and ciliates. The number of taxa and their abundance differed significantly between the sampling sites. The prospected habitats supported different protist assemblages, proved by ordination analysis. The most distinctive habitat was the hygropetric. Habitat heterogeneity could be attributed to the presence of inorganic and organic sediments at the sites and habitat microhydrology (lotic or lentic system). Kendall's concordance coefficient showed a good synchronicity between the habitats in the Veternica cave, based on taxon richness and abundance of protists indicating similar seasonal trends. Seasonality in the studied habitats is attributed to the hydro-meteorological conditions in the Veternica cave drainage area. This study is one of the few studies of spatio-temporal diversity and abundance of protists in caves. Despite the similar appearance of small transitional and aquatic habitats in caves, an example of this study showed specific habitat diversification.
\end{abstract}

Copyright Najla Baković et al. This is an open access article distributed under the terms of the Creative Commons Attribution License (CC BY 4.0), which permits unrestricted use, distribution, and reproduction in any medium, provided the original author and source are credited. 


\section{Keywords}

Bat's guano, cave protists, clay pools, habitat heterogeneity, heliozoan, hygropetric, seasonality in cave, sinter pools, spatio-temporal dynamics, testate amoebae

\section{Introduction}

Freshwater karst caves are formed in soluble rock such as limestone or dolomites by dissolution processes induced by rainwater that is slightly acidic by dissolved $\mathrm{CO}_{2}$ from the atmosphere and also biogenically produced within soil layers (Ford and Williams 2007). In opposite to cave entrances, the deeper parts of the caves have relatively constant microclimatic conditions (temperature, high humidity) and absolute absence of sunlight. The subterranean karst habitats are extending, not only within caves, but also in other parts of the bedrock where dissolution has created voids large enough to be inhabited by living organisms (Culver and Pipan 2009). In other words, caves are just small windows into much larger habitats: the vadose and phreatic zone of the karstified bedrock.

The majority of current cave research was focused on animals that are often highly endemic and exhibit morphological, behavioural and physiological adaptations to their environment (Culver and Pipan 2009). Other organisms in these ecosystems, such as fungi and various microorganisms have been neglected and very little data is known about their biodiversity and ecology (Gottstein Matočec et al. 2002; Moldovan et al. 2018).

Nevertheless, many researchers have made contributions to our knowledge of cave protists, even though these are mostly based on on-off sampling. To date, several hundred species of cave protists from all continents have been discovered. In their comprehensive work, Gittleson and Hoover $(1969,1970)$ reviewed the literature on protists in caves around the world, and reported more than 400 species. Researchers from Italy contributed predominantly to the knowledge of ciliates in caves (Coppellotti and Guidolin 1999; Coppellotti Krupa and Guidolin 2003; Luca et al. 2005) and studies of naked (Bastian et al. 2009; Walochnik and Mulec 2009; Mulec et al. 2016) and testate amoebae (e.g. Chibisova 1967; Golemansky and Bonnet 1994; Mazei et al. 2012; Baković et al. 2019) were also done.

Most protists species found in caves have been previously registered in non-cave habitats, and many of them were allocated as euribiotic species (Golemansky and Bonnet 1994). Although few protists species or forms have been described from caves (Chibisova 1967; Walochnik and Mulec 2009), some of them have been found later in surface habitats or have been found as synonyms with previously described species.

The ecology of cave protists has very scarcely been investigated. The main gaps in studies on the subterranean protist ecology is the lack of quantitative methods, as well as precise and thus comparable habitat characterisation (e.g. Vandel 1965; Gittleson and Hoover 1969). Comparing data from particular habitats is also complicated by inconsistency in terminology and by often inadequate species descriptions that make correct identification impossible (Lahr et al. 2012; Kosakyan et al. 2016). Also, it is not always clear whether samples were taken within the cave entrance, where light was also present and affecting the communities, or in a truly subterranean habitat. The diversity 
of protists was studied in mostly aquatic habitats like subterranean streams, lakes and various smaller water pools that formed inside the caves (Vandel 1965; Gittleson and Hoover 1969, 1970). Some data refer to cave sediments and transitional habitats characterized by water layers present on solid surfaces, biofilms and fungal mycelia biomass (Golemansky and Bonnet 1994; Coppellotti and Guidolin 1999; Coppellotti Krupa and Guidolin 2003; Bastian et al. 2009; Garcia-Sanchez et al. 2013). Epibiotic protists were registered on cave-dwelling animals (Matjašič 1962; Dovgal and Vargovitsh 2010).

This research represents the continuation of the study of protists in the Veternica cave in the Medvednica mountain in Croatia. The impact of hydro-meteorological conditions on the protist assemblages in this cave was discussed by Kajtezović and Rubinić (2013). Findings of some protists within the lampenflora in the Veternica cave were mentioned by Baković (2016). Baković et al. (2019) described a new species of testate amoebae, Centropyxis bipilata, from caves of the Dinaric Arc, which was also present in the Veternica cave.

The aim of this study was to investigate the spatio-temporal taxon richness and abundance of protists present in the Veternica cave. We also compared various habitats in order to test how habitat heterogeneity within this cave affects protist assemblages. This research is, to our knowledge, one of the few studies of spatio-temporal changes in taxon richness and abundance of protist taxa in freshwater karst caves.

\section{Methods}

\section{Study site}

The Veternica cave is a complex speleological object located in the southwestern part of the Medvednica mountain $\left(45^{\circ} 50^{\prime} 27.22^{\prime \prime} \mathrm{N}, 15^{\circ} 52^{\prime} 24.75^{\prime \prime} \mathrm{E}\right)$ at an altitude of $330 \mathrm{~m}$ above sea level (Fig. 1). The full length of the horizontal cave channels is 7,128 m (Fig. 2). It was dominantly formed between the Triassic dolomite and Miocene limestone (Lacković et al. 2011). The first $380 \mathrm{~m}$ of the cave is open for organized tourist visits from March to November. In winter, this cave is a nationally important hibernaculum for bats with over 1000 individuals, and in summer there is one maternity colony present near the cave entrance (Petra Žvorc, pers. comm.). In this cave there is air circulation during the summer months (blowing out of the cave) and winter months (outside air entering the cave).

The research was conducted from October - December 2011 and February - April 2012 at six cave sites with three habitat types: sinter pools (site SP-1, SP-2), clay pools (site CP-1, CP-2) and hygropetric (site HP-1, HP-2). Sampling at sites SP-1 and CP-1 was not performed in October 2011 due to technical difficulties. All sampling sites were out of reach of sunlight. During the research, pre-hibernation and hibernation colonies of bats (mostly Rhinolophus spp.) were present.

Sinter pools (SP) in this investigation represented small cascade pools on speleothems filled with water. They were created by gradual precipitation and dissolution of calcium carbonate from seeping water. At this specific location, cascades of sinter pools were of very small depth, ranging from a few millimetres to several centimetres. Slowly dripping water from the speleothems above this habitat contributes to the constant presence of wa- 


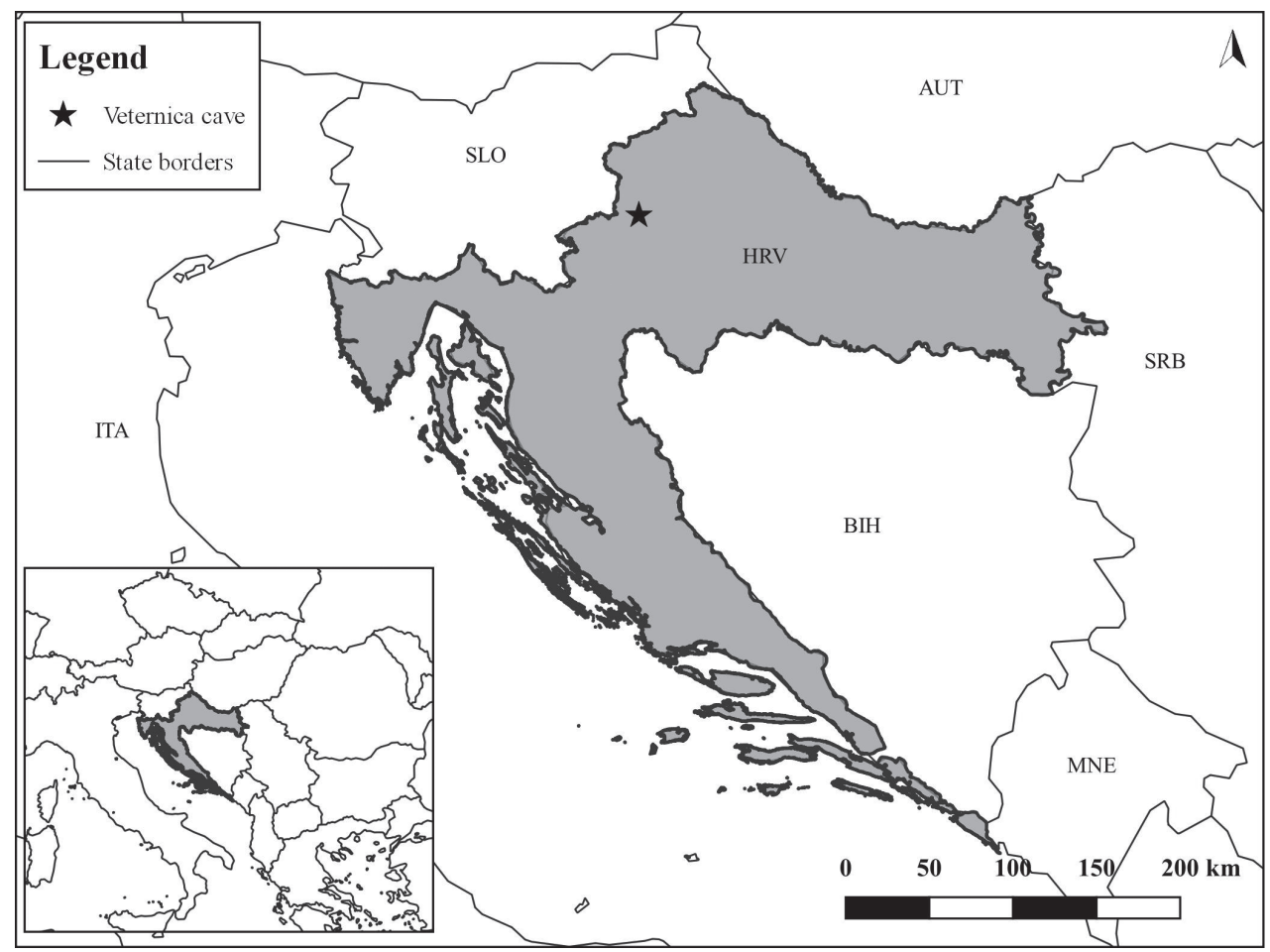

Figure I. Location of the Veternica cave.

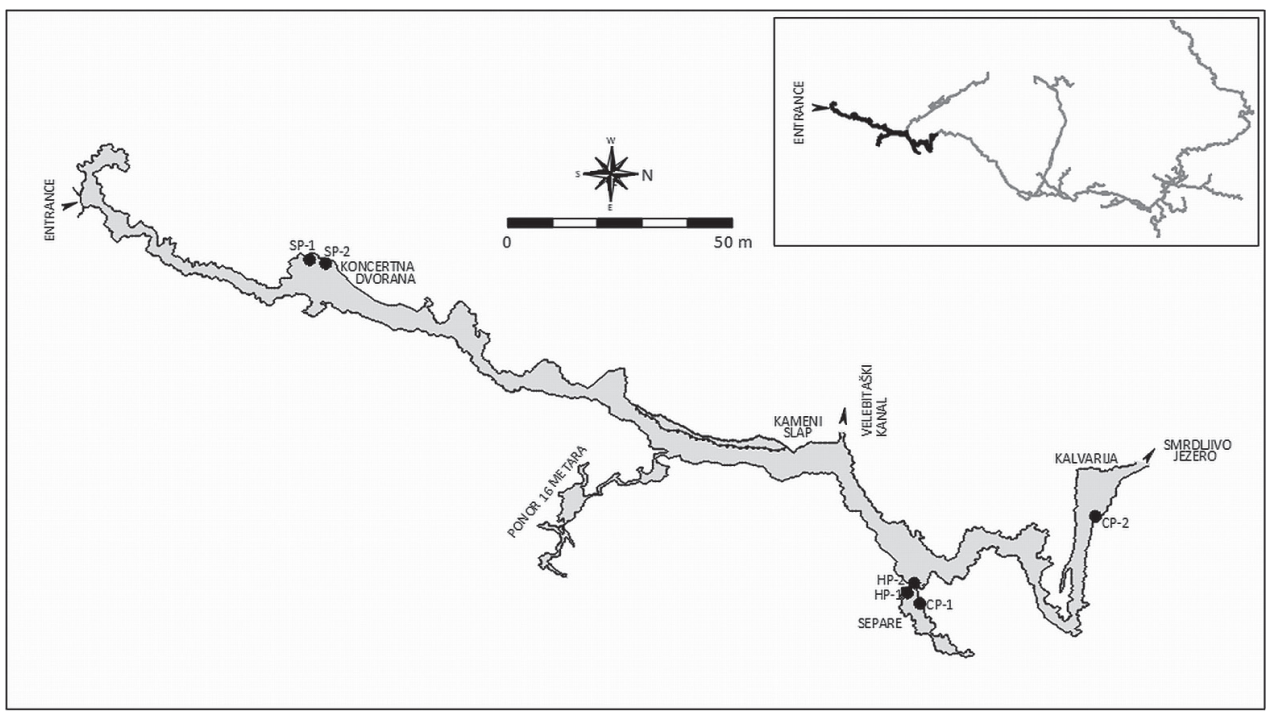

Figure 2. Map of the Veternica cave [adapted from Čapelak (1979)] with marked sampling sites (CP-clay pools; SP-sinter pools and HP-hygropetric). 
ter. Samples were taken at Koncertna dvorana, located in the main cave channel, at a distance of $90 \mathrm{~m}$ from the cave entrance; the distance between SP-1 and SP-2 is about $1.5 \mathrm{~m}$.

Clay pools (CP) are small pools in cave clay deposits filled with water. They are created by the constant dripping of water from the speleothems onto clay deposits. The depth of these pools varies from a few millimetres to several centimetres. Site CP-1 was located in a small side channel named Separe (about $1.8 \mathrm{~m}$ from stations HP-1 and HP-2), the distance to the cave entrance is about $250 \mathrm{~m}$. Site CP-2 was located in a hall named Kalvarija, at a distance of about $380 \mathrm{~m}$ from the cave entrance. The distance between site CP-1 and CP-2 was about $100 \mathrm{~m}$.

Hygropetric (HP) is a habitat type characterized by a thin layer of water $(-1 \mathrm{~mm})$ constantly seeping onto the surface of speleothems. Location in the cave: a small side channel named Separe, distance to the cave entrance is about $250 \mathrm{~m}$; distance between sites HP-1 and HP-2 is $1.2 \mathrm{~m}$.

\section{Sampling, measurements and identification}

Cave air temperature and cave relative air humidity were measured using the Kestrel 3000 instrument.

Plastic containers were filled with $40 \mathrm{ml}$ of tap water. Water and bottom sediment from sinter and clay pools were transferred into the prepared containers using graduated plastic pipettes. Additionally, solid surfaces of sinter pools were rubbed with plastic brushes and the collected sediment was afterwards transported into the plastic containers by repeated "washing" the brush in the collected water in the container. Samples from the cave hygropetric were collected by rubbing its surface with plastic brushes and repeated "washing" the brush in the water in the container.

The collected samples contained water, mineral particles and bats guano (if present in the habitat). Samples were maintained at temperatures of $4-10{ }^{\circ} \mathrm{C}$ and prospected within 48 hours after sampling. After decantation, a mixture of sediment and water was taken and a triplet of $0.2 \mathrm{ml}$ (total $0.6 \mathrm{ml}$ ) samples were prospected and data on diversity of protist taxa were noted, together with the taxon richness of the accompanying meiofauna. The number of individuals of each protist taxa in prospected volume (total of $0.6 \mathrm{ml}$ ) was counted. The abundance of protist taxa in $1 \mathrm{ml}$ was estimated based on the data of the abundance in $0.6 \mathrm{ml}$ of prospected volume. Diversity and abundance were estimated using a Carl Zeiss Primostar light microscope. The presence of guano in the collected sample was estimated by using insects leftovers as indicators (exoskeleton fragments, butterfly wings scales) and their aggregations on the microscopy slide (present in fresh guano deposits rich also in non-chitin material). It was rated according to the following scale: 0 - absent (no traces of insects leftovers), 1 - low quantity (up to ten insects leftovers in the sample, leftovers are not aggregated), 2 - medium quantity (eleven or more insects leftovers present, leftovers are not aggregated), 3 - high quantity (aggregation of insects guano is present regardless of number of insects leftovers).

The samples were scanned for protists using a Nikon Diaphot inverted light microscope and a Carl Zeiss Primostar. Selected cells were examined in detail with the 
Primostar in higher magnifications or with an Olympus BX51 light microscope with differential interference contrast (DIC) and Phase Contrast optics.

Additional samples were collected in July 2020 to confirm the identification of heliozoans from the sinter pools (SP). Drops of this material were pipetted onto light microscope slides and covered with a slip. These slides were kept in a humidity chamber for several days and observed for heliozoans and naked amoebae. When heliozoans had established their populations after several days, the slip was gently removed and the slide was left to dry. This air-dried material, containing plate and spine-scales of heliozoans, was photographed with FEM-REM Zeiss Neon by Steffen Clauß in Chemnitz (Germany) to facilitate their identification.

Specimens were identified by genus and, if possible, by species level, mainly based on the following references: ciliates: Kahl 1930; Foissner et al. 1991, 1992, 1994, 1995; Foissner and Berger 1996; naked amoebae and heliozoa: Page and Siemensma 1991; testate amoebae: Ogden and Hedley 1980; Mazei and Tsyganov 2006; Tsyganov et al. 2016.

\section{Data analysis}

Data about the taxon richness and abundance between the sampling sites were analysed using descriptive statistics in Statistica software and MS Office Excel.

Differences in the number of taxa and the abundance between the sites were analysed using Friedman's ANOVA, a nonparametric alternative of one-way repeated measures ANOVA. The analyses were done in Statistica 13 (TIBCO Software Inc.). Similarities between protist assemblages were tested using the Bray-Curtis similarity, which was used for nMDS analysis. The latter analysis was done in PRIMER6 (PRIMER-e Ltd).

\section{Results}

The largest variability of the microclimate in the Veternica Cave was recorded in Koncertna dvorana - the air temperature ranged from $4.1{ }^{\circ} \mathrm{C}$ (Feb 2012) to $10.5^{\circ} \mathrm{C}$ (Oct 2011), while the relative air humidity ranged from 70.7\% (Mar 2012) to 91.5\% (April 2012). The air temperature in Separe ranged from $8.1{ }^{\circ} \mathrm{C}$ (Dec 2011) to $10.7{ }^{\circ} \mathrm{C}$ (Oct 2011), while the relative air humidity ranged from $77.7 \%$ (Feb 2012) to $81.6 \%$ (Nov 2011). The air temperature in Kalvarija ranged from $7.5^{\circ} \mathrm{C}$ (Feb 2012) to $11.2{ }^{\circ} \mathrm{C}$ (Oct 2011), while the relative air humidity ranged from 82.2\% (Oct 2011) to 90.8\% (April 2012).

A total of 47 taxa of protists belonging to heterotrophic flagellates, ciliates, heliozoans (Fig. 3) and testate (Fig. 4) and naked amoebae were recorded (Table 1). Protists were not registered in the samples from HP-1 on 2/2012 and HP-2 on 12/2011. Taxon richness was highest within ciliates and testate amoebae (both 16 taxa). Less diverse groups were naked amoebae (6), heterotrophic flagellates (6), heliozoans (2) and stramenopiles (1).

After six months of research, the sites with the highest taxa number were SP-2 (36 taxa), SP-1 and CP-1 (both 20 taxa). A somewhat lower taxon richness was recorded at site CP-2 (17 taxa). 

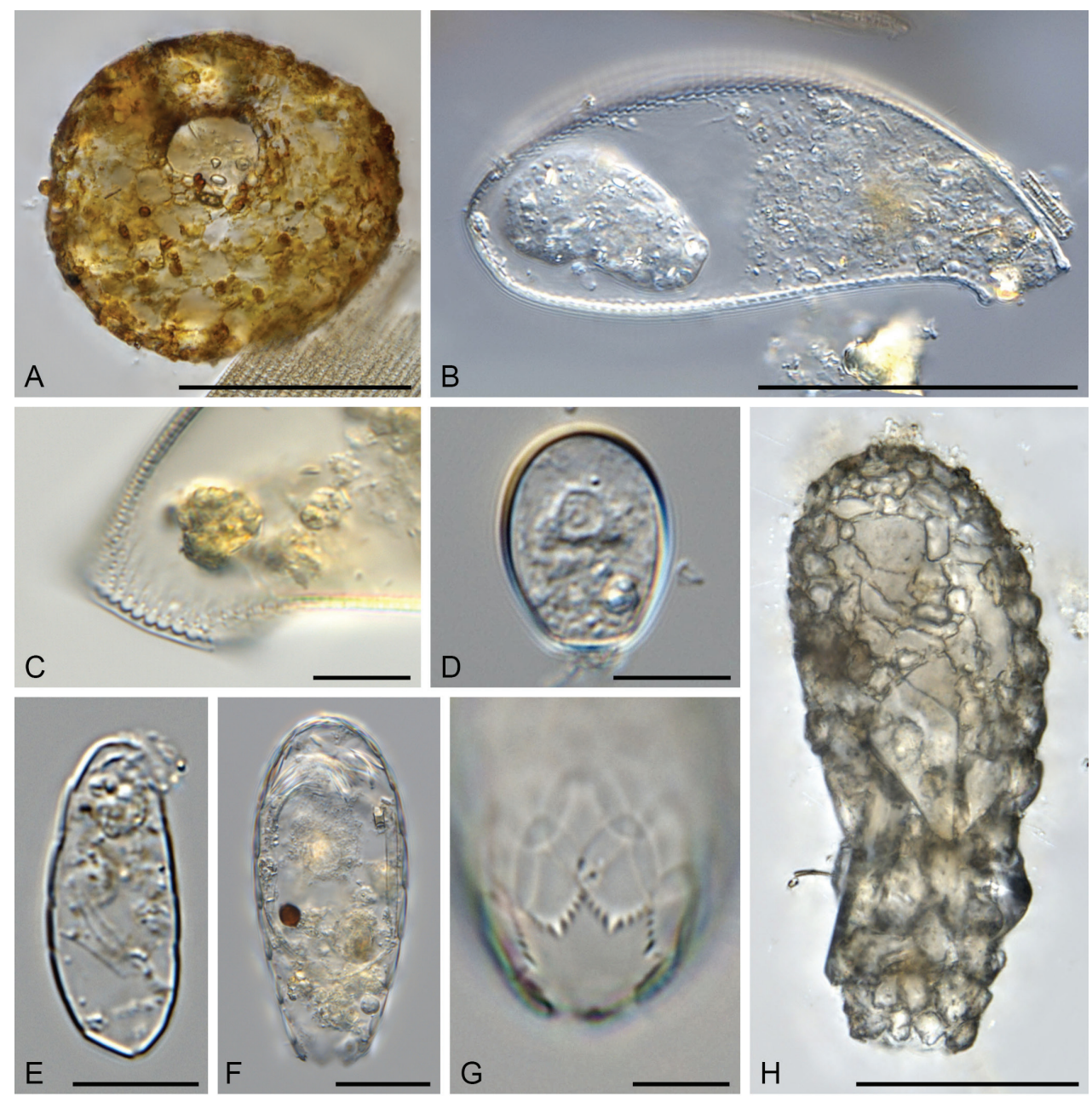

Figure 3. A Centropyxis bipilata; B, C Cyphoderia ampulla B test C collar C Cryptodifflugia oviformis $\mathbf{E}$ Trinema lineare $\mathbf{F}, \mathbf{G}$ Euglypha tuberculata $\mathbf{F}$ test $\mathbf{G}$ aperture $\mathbf{H}$ Difflugia oblonga. Scale bars: $50 \mu \mathrm{m}$ $(\mathbf{A}, \mathbf{B}, \mathbf{H}) ; 20 \mu \mathrm{m}(\mathbf{F}) ; 10 \mu \mathrm{m}(\mathbf{C}-\mathbf{E}, \mathbf{G}) ;$ light microscopy.

Occasionally, resting stages (cysts) morphologically typical of amoeboid protists were found at sites SP-1, SP-2 and CP-1. Some of them were present in testate amoebae shells.

Meiofauna was occasionally registered in all habitats: SP (Rotifera, Nematoda, Turbellaria, Copepoda, Oligochaeta, Hydrachnidia, insect larvae), CP (Rotifera, Nematoda, Hydrachnidia, Oligochaeta, insect larvae) and HP (Nematoda, Hydrachnidia, Copepoda).

Taxon richness and abundance of protists were higher in habitats SP and CP, compared to HP (Fig. 5; Table 2). The standard deviation of the SP and CP habitats was also greater than of the hygropetric habitats. The number of taxa differed significantly between sites (Friedman's ANOVA, $\chi(\mathrm{n}=5$, d.f. $=5)=17.53, \mathrm{p}<.01$ ), with Kend- 
Table I. Protist taxon richness on research sites.

\begin{tabular}{|c|c|c|c|c|c|}
\hline \multirow{2}{*}{ Taxa } & \multicolumn{5}{|c|}{ Research sites } \\
\hline & SP-1 & SP-2 & CP-1 & CP-2 & HP-1 HP-2 \\
\hline
\end{tabular}

\section{Testate amoebae}

Arcella artocrea Leidy, 1876

Arcella rotundata Playfair, 1918

Centropyxis aerophila Deflandre, 1929

Centropyxis bipilata Baković, Siemensma, Baković, Rubinić, 2019

Centropyxis laevigata Penard, 1890

Cryptodifflugia oviformis Penard, 1902

Cyclopyxis sp.

Cyphoderia ampulla Ehrenberg, 1840

Difflugia oblonga Ehrenberg, 1838

Difflugia sp.

Euglypha laevis (Ehrenberg, 1832) Perty, 1849

Euglypha rotunda Wailes, 1915

Euglypha sp.

Euglypha tuberculata Dujardin, 1841

Tracheleuglypha dentata Deflandre, 1928

Trinema lineare Penard, 1890

\section{Heliozoa}

Acanthocystis myriospina Penard, 1890, emend. Dürrschmidt, 1985*

Raphidocystis marginata (Siemensma, 1981) Zlatogursky, 2018*

\section{Ciliophora}

Ciliophora 1

Ciliophora 2

Ciliophora 3

Cinetochilum margaritaceum Perty, 1849

Colpoda sp.

Colpoda steini Maupas, 1883

Cyclidium glaucoma O.F.M., 1786

Cyrtophoryda

Glaucoma sp.

Hymenostomata 1

Hymenostomata 2

Litonotus Lamella Schewiakoff, 1896

Nassulida 1

Nassulida 2

Pleuronema sp.

Sphatidium sp.

\section{Stramenopiles}

Actinophrys sol Ehrenberg, 1830

\section{Heterotrophic flagellates}

Nanoflagellata (five taxa)

Peranema trichophorum (Ehrenberg 1838) Stein 1878

\section{Naked amoebae}

Amoebozoa 1

Amoebozoa 2

Korotnevella sp.

Mayorella sp.

Rhizamoeba sp.

Vahlkampfia sp.

$\begin{array}{llllll}- & + & - & - & - & - \\ - & - & - & - & - & + \\ + & - & - & - & + & + \\ - & + & - & - & + & - \\ - & + & - & - & - & - \\ + & + & + & - & - & - \\ + & - & - & - & + & + \\ - & + & - & + & - & - \\ - & + & - & - & - & - \\ - & + & - & - & - & - \\ + & + & + & + & + & + \\ - & + & - & - & - & - \\ + & - & - & - & - & + \\ - & + & - & + & - & - \\ - & + & - & + & - & - \\ + & + & + & + & + & -\end{array}$

*In addition, specimens of the heliozoan Raineriophrys erinaceoides (Petersen \& Hansen, 1960) Mikrjukov, 2001 were found in the 2020 samples. 

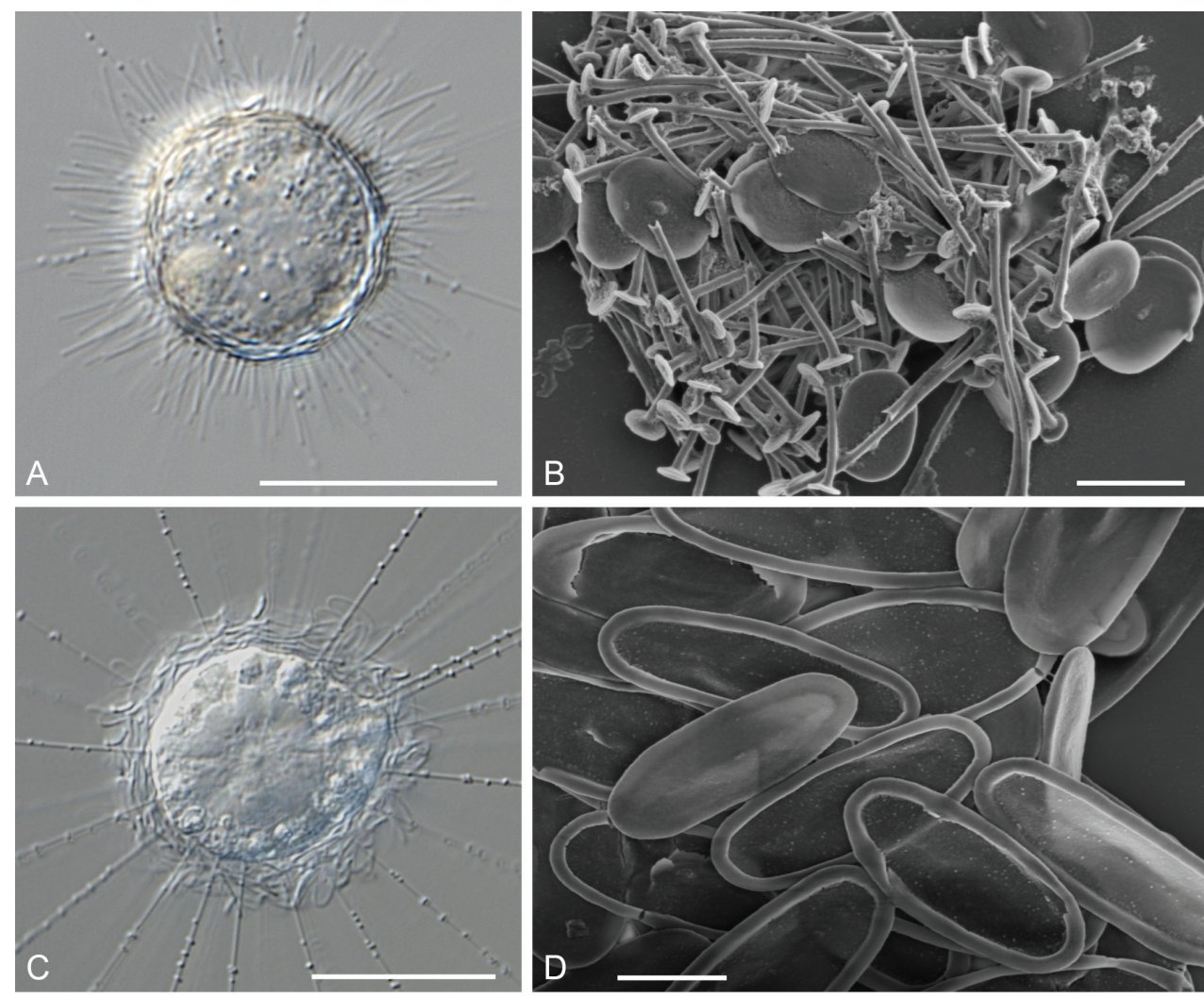

Figure 4. A, B Raphidocystis marginata A LM micrograph of a living cell B REM micrograph of plate-scales and spine-scales C, D Acanthocystis myriospina $\mathbf{C}$ LM micrograph of a living cell D REM micrograph of plate-scales. Scale bars: $20 \mu \mathrm{m}$ (A, C); $2 \mu \mathrm{m}$ (B, D); LM, light microscopy; REM, raster electron microscopy.

all's concordance coefficients $(\tau)$ of .70 indicating good synchronicity between sites. There was also significant difference in protist abundance between the sites (Friedman's ANOVA, $\chi(\mathrm{n}=5$, d.f. $=5)=17.34, \mathrm{p}<.01)$. As with the number of taxa, there was a good synchronicity between all habitats $(\tau=.69)$.

The composition of protist assemblages (Table 1) shows that ciliates, testate amoebae and flagellates were present in all habitats researched. In habitats SP and CP, dominant taxa were ciliates, testate amoebae and flagellates, but with unclear dominance within the individual site. Naked amoebae, stramenopiles and heliozoans were not recorded in the hygropetric at all. When present, they were less dominant compared to other groups. Naked amoebae were absent in CP-2.

In habitat HP testate amoebae were the dominant group with 63.6\% (HP-1) and $50 \%$ (HP-2) of taxa, followed by the flagellates and ciliates.

Non-metric MDS plot, based on Bray-Curtis similarity between protist assemblages, suggested possible differentiation within prospected habitats (Fig. 6). The most distinctive was the hygropetric habitat. The similarity was somewhat higher within sinter pools, while clay pools showed some lower distinction. 

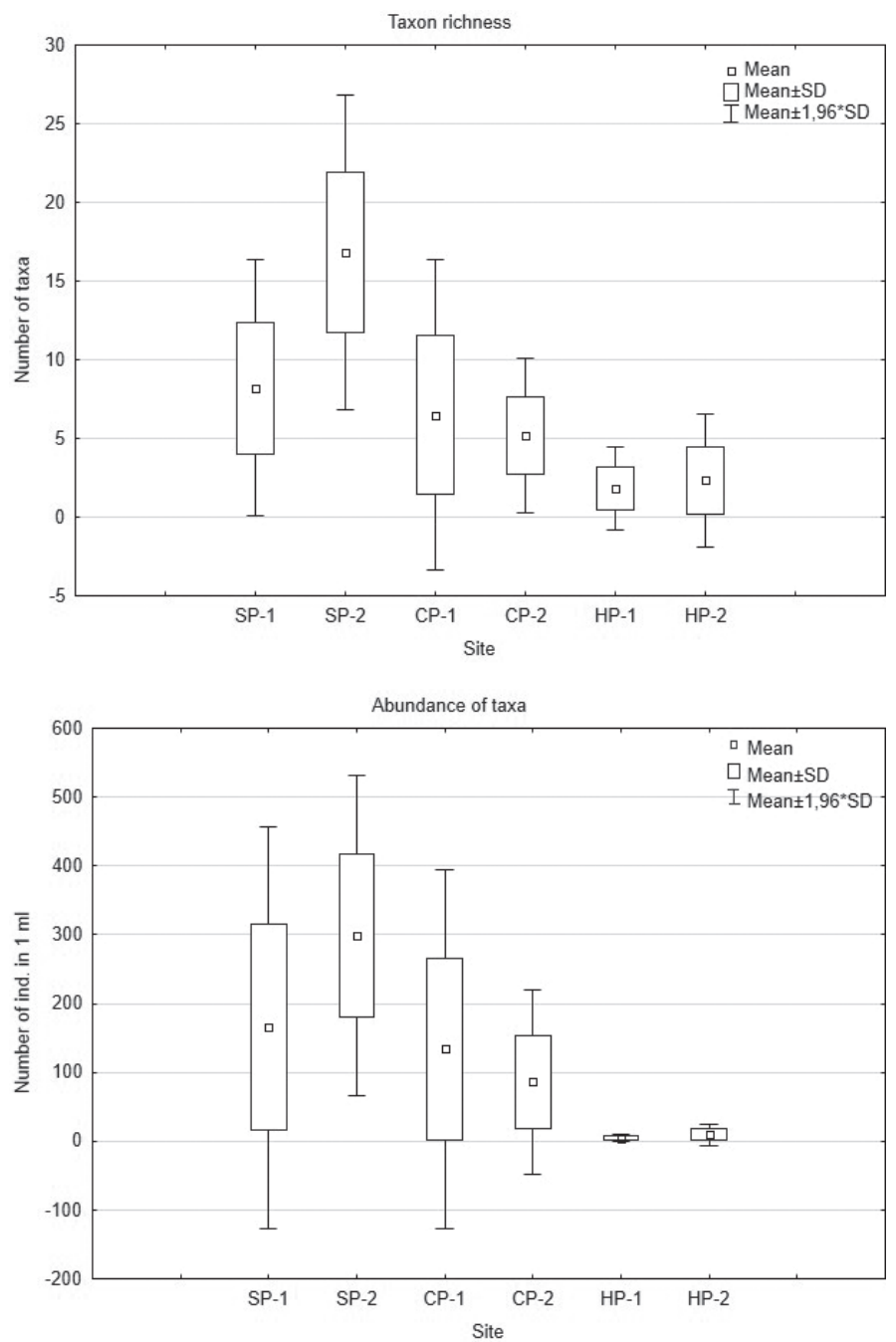

Figure 5. Taxon richness and abundance of protist taxa at the sites investigated.

Table 2. Abundance of protist taxa at the investigated sites.

\begin{tabular}{lcccccc}
\hline \multirow{2}{*}{ Date } & \multicolumn{7}{c}{ Protist taxa abundance (number of individuals in 1 $\mathbf{~ m l}$ ) on research sites } \\
\cline { 2 - 6 } & SP-1 & SP-2 & CP-1 & CP-2 & HP-1 & HP-2 \\
\hline October 2011 & $\mathrm{n} / \mathrm{a}$ & 270.00 & 10.00 & $\mathrm{n} / \mathrm{a}$ & 8.33 & 3.33 \\
November 2011 & 91.67 & 220.00 & 256.67 & 3.33 & 5.00 & 18.33 \\
December 2011 & 288.33 & 351.67 & 278.33 & 131.67 & 5.00 & 0 \\
February 2012 & 75.00 & 191.67 & 1.67 & 80.00 & 0 & 20.00 \\
March 2012 & 13.33 & 246.67 & 30.00 & 41.67 & 6.67 & 8.33 \\
April 2012 & 358.33 & 513.33 & 226.67 & 173.33 & 3.33 & 6.67 \\
Number of samples & 5 & 6 & 6 & 5 & 6 & 6 \\
Minimum & 13.33 & 191.67 & 1.67 & 3.33 & 0 & 0 \\
Maximum & 358.33 & 513.33 & 278.33 & 173.33 & 8.33 & 20.00 \\
Average & 165.33 & 298.89 & 133.89 & 86.00 & 4.72 & 9.44 \\
Median & 91.67 & 258.33 & 128.33 & 80.00 & 5.00 & 7.50 \\
\hline
\end{tabular}




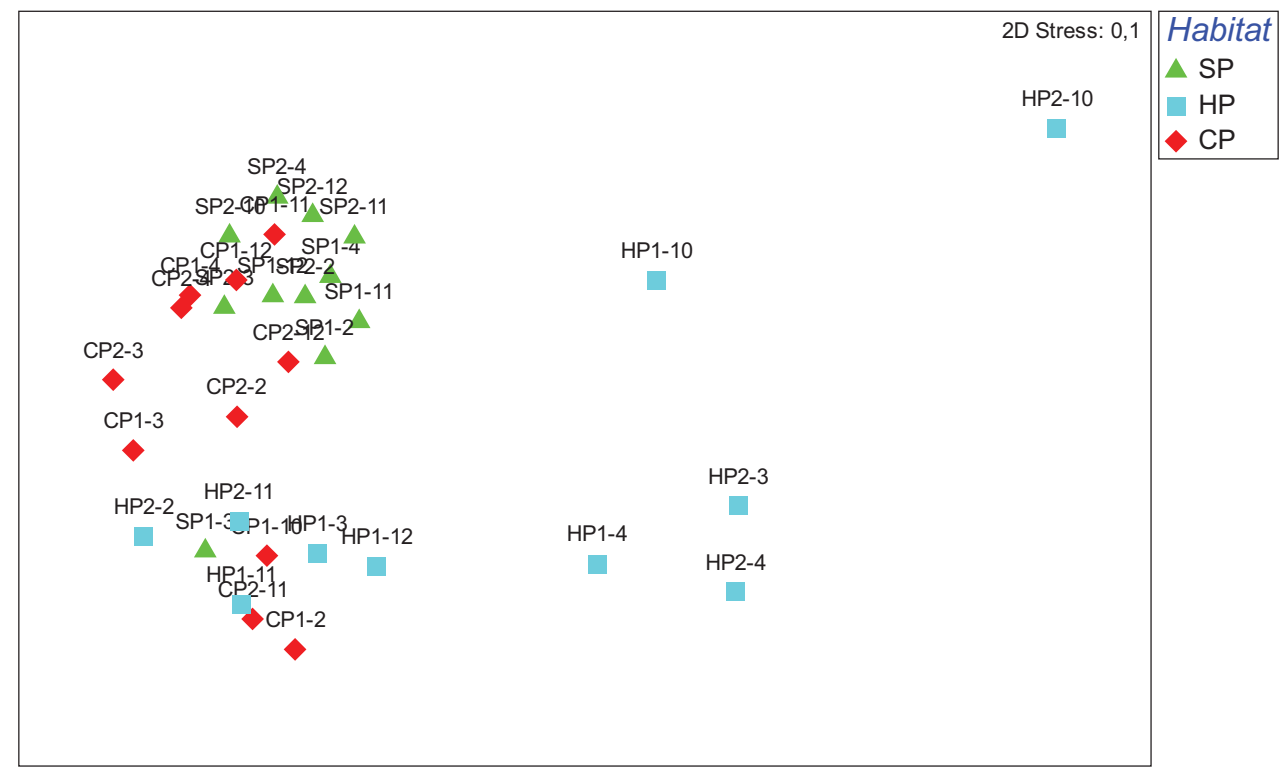

Figure 6. nMDS based on Bray Curtis similarity between samples.

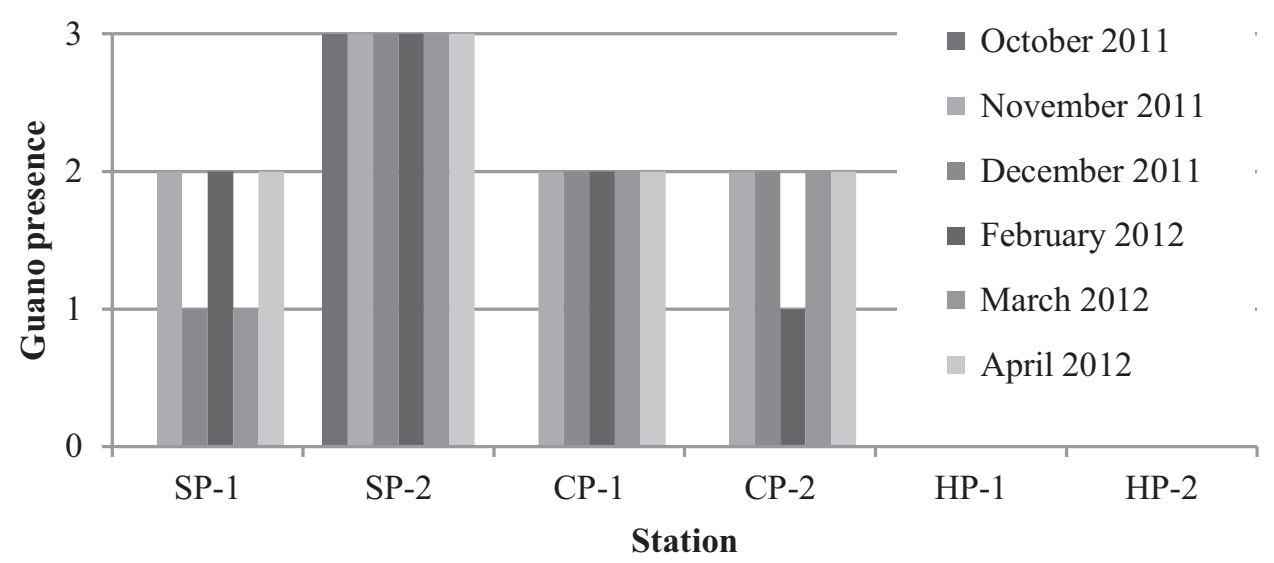

Figure 7. Presence of guano on researched habitats ( 0 - absent, 1 - low quantity, 2 - medium quantity, 3 - high quantity).

Guano was absent in the hygropetric, while in other habitats it was present in variable quantities (Fig. 7). Only in SP-2, guano was of high quantity during the whole research.

\section{Discussion}

In this research, 47 taxa of protists (Table 1) were distinguished in the Veternica cave in a short period of six months and in only six sites (3 habitats). This result implies that the 
protist taxon richness could be higher compared to other animals inhabiting the caves. The six-month research of protists in the Mexican cave Cueva de Los Riscos (SigalaRegalado et al. 2011) revealed only 13 taxa of protists. The authors did not report of testate amoebae, even though they are very diverse in subterranean habitats (Mazei et al. 2012). On the other hand, the taxon richness of testate amoebae recorded in the Veternica cave during this research showed that they were present in all habitats and stations. The research in caves of the Dinaric Arc (south-eastern Europe) showed that the biodiversity of testate amoebae varies depending on the individual cave and sampling efforts (Baković et al. 2019). Testate amoebae diversity in caves from Italy and Russia was also higher in heterogeneous caves (Mazei et al. 2012). Except for the habitat characteristics, significant differences could be attributed to different methodologies. For example, research in the Grotta del Mulino cave (Italy), that included intensive laboratory experiments, revealed 129 taxa of protists in the collected samples (Luca et al. 2005).

Protists found in the Veternica cave are mostly taxa that have been registered by other researchers in non-cave habitats (i.e. Gittleson and Hoover 1969; Mazei et al. 2012). However, the recently described testate amoeba Centropyxis bipilata has been reported from the Veternica cave (Baković et al. 2019), showing that this cave supports potentially interesting assemblages. C. bipilata is distributed within caves of the Dinaric karst and the Veternica cave represents the only isolated karst area where this species was found. These findings imply that caves may be an additional habitat for some widely distributed protists or possibly the only habitat for species found exclusively in caves. As protists in general are still scarcely investigated, especially in soil (Foissner 1997), this hypothesis could not be yet confirmed with certainty.

Some taxa, registered in the Veternica cave (Table 1), could indicate variable saprobity at the prospected sites. For example, the ciliates Cyclidium glaucoma and Cinetochilum margaritaceum that were common in habitats with guano (Fig. 7), were absent in the hygropetric. The presence of taxa indicative for a some higher saprobic index in caves (Coppellotti Krupa and Guidolin 2003) is implying strong influence of guano as one of the factors that is determining taxa composition. On the other hand, site HP is characterized by the absence of naked amoebae, heliozoans, stramenopiles, predatory ciliates and larger taxa of testate amoebae (e.g. Difflugia oblonga, Euglypha tuberculata) (Table 1). Taxon richness and abundance (Fig. 5; Table 2) were also lower in this habitat. These results are in concordance with the statement that some subterranean habitats are characterized by simple food webs, consisting out of small number of species (Moldovan et al. 2018). Results from the Veternica cave are showing that in the same cave various trophic conditions could be present. Guano in caves is supporting not only microorganisms, but also groups of specialized organisms called guanophiles and guanobionts (Moldovan et al. 2018). As the taxon richness of meiofauna in the Veternica cave was richest in habitats with guano, it could not be excluded that their presence influenced protist taxa composition and abundance, thus making the habitats with guano in the Veternica cave more distinctive than habitats without guano.

It should be noted that the presence or absence of certain species or taxa in the samples cannot always be reliably detected. Testate amoebae are still relatively easy to register and identify from their (usually empty) shells, although here too it is sometimes 
not always possible without observing living specimens for their pseudopodia (lobose or filose). Naked amoebae are much more difficult to detect, as they can die or encyst fairly quickly in the material being transported. For this group, wet slides kept in moist chambers for some time can reveal several species. The same goes for heliozoans. At present, heliozoans can only be reliably identified by SEM.

As the Veternica cave has a large number of visitors, they could also impact taxon richness. It is experimentally confirmed that visitors have strong impact on dispersion of microorganisms and seeding of species not typically found in caves (FernandezCortes et al. 2011; Mulec 2014; Mulec et al. 2017). For example, the entrance of the Veternica cave has numerous small water pools that visitors are stepping to before entering the cave. These human vectors of transport could be also attributed to the living protists and especially their encysted stages that are smaller and lighter (i.e. even more easily transferred). Findings of protist cysts in prospected habitats in the Veternica cave imply that some present taxa may have been introduced as cysts.

Results of the nMDS analysis showed a specific grouping within the researched sites (Fig. 6). When comparing the taxon richness and abundance between habitats in this research some variability can be observed (Fig. 4; Table 2). The most distinctive characteristic of HP is a low taxon richness and also a relatively narrow spread of taxon richness over six months of research compared with SP and CP. A low abundance of protists in $\mathrm{HP}$ is, in contrast to SP and CP, even more distinct. On two occasions, protists were not detected in HP. Negative results from cave samples were also mentioned by other authors (Delhez and Chardez 1970; Golemansky and Bonnet 1994) implying occasional conditions with low energy input. When these conditions are present, the protists communities are undetectable by the sampling methodology used in this research. Considering that guano was absent in all samples of HP, this habitat, in contrast to habitats SP and CP, is very poor in organic matter, which is probably the cause of low taxon richness and abundance.

The differences between individual sites of habitats SP and CP can be explained by the temporal variability of bat guano (Fig. 7). Research in the Veternica cave corresponded with the period of pre-hibernation and hibernation of the large bat colony, so their droppings found on the researched habitats were of variable age. Taxon richnes was highest on SP-2 (36 taxa) (Table 1; Fig. 7) where guano was of the highest quantity. Research of naked amoebae in the guano habitats of some Slovenian caves showed that their taxon richness is higher in fresh guano deposits, while they were absent in guano deposits that were several decades old (Mulec et al. 2016). Our results are in agreement with the mentioned findings, as the naked amoebae were most diverse at site SP-2 with the highest guano quantities during the whole research period (Fig. 7). Also, naked amoebae have not been recorded in the hygropetric that lacked guano during the whole research period (Table 1).

The modifying effect of guano in the Veternica cave can have several consequences. Bat guano represents a rich food source for protists, thus it increases taxa abundance. This was also reported by some other researchers (e.g. Golemansky and Bonnet 1994). A higher abundance of all organisms (including bacteria) establishes complex food webs that support more taxa. It also means that some potentially rare taxa are more likely to 
be discovered. A second impact of guano is the establishment of more diverse microhabitats that can be colonized by protists. Due to the small number of materials present in caves (both organic and inorganic), a limited number of habitats can be formed. The presence of guano in a habitat can increase the heterogeneity in a specific location due to the large number of insect chitin leftovers in the guano that could provide shelter for microorganisms. They serve as an additional microhabitat for some taxa. From the perspective of microorganisms, habitats in caves are more diverse for them than for multicellular organisms. Guano certainly increases this heterogeneity further.

Except for the mentioned energy input to the habitats, the factors that are contributing to the distinction of the habitats showed by mMS (Fig. 6) could be related to other habitat characteristics. The difference between SP and CP protist assemblages, even though these habitats appear almost similar, can be attributed to differences in sediment on their bottoms. The bottom of SP is made of calcite minerals that create a heterogeneous surface due to the spaces between the mineral grains. These spaces can be used by protists. On the other hand, clay creates a compact and homogenous surface. The low permeability of clay prevents the formation of additional habitats. Clay deposits, as distinctive habitat of protists, was also mentioned by Vandel (1965).

The differences between habitats can also be attributed to their microhydrology. SP and CP are actually small lentic habitats within caves with the ability to held sediments. Retention of sediments, especially bat guano, significantly increases the energy input to these habitats. As already mentioned, higher abundance and taxon richness of protists in habitats with bat guano and cricket excrements has already been observed in caves (Gittleson and Hoover 1970; Golemansky and Bonnet 1994; Mulec et al. 2016). Findings of heliozoans and the large stramenopile Actinophrys sol exclusively in SP and $\mathrm{CP}$, indicate conditions closer to surface lentic habitats, even though these habitats are characterized by shallow and very small water pools. The HP, on the other hand, is better described as a lotic habitat as the water seeps constantly on the walls surface, so there is no significant water or sediment retention. Thus, the hygropetric is a food deprived environment compared to SP and CP.

Good synchronicity between the different habitats in the Veternica cave indicates similar seasonal trends in diversity and abundance of protists. As the Veternica cave microclimate showed relatively small variations and considering the constant absence of light, the cause of similar seasonal trends could be a reflection of the hydro-meteorological conditions in the cave drainage area. The water coming from the surface transports organic matter to the cave ecosystems (Simon et al. 2007) which affect the subterranean food webs. The connection between discharge events and diversity and abundance of microorganisms has already been noted in karst aquifers (Wilhartitz et al. 2013; Benk et al. 2019). The impact of hydro-meteorological conditions on protist assemblages in the Veternica cave (that was performed on the same dataset as this research), was also confirmed by Kajtezović and Rubinić (2013) using the regression tree algorithm. Thus, it can be concluded that surface hydro-meteorological conditions have a relatively homogenized impact on the subterranean protist assemblages in the prospected habitats in the Veternica cave. As the significant differences in spatio- 
temporal taxon richness and abundance in habitats existed, despite the seasonal synchronicity between habitats, it can be assumed that protist assemblages in the Veternica cave are shaped both by hydro-meteorological conditions in the cave drainage area together with already present conditions in the cave.

\section{Conclusion}

This research presents one of the rare studies of spatio-temporal taxon richness and abundance of protist assemblages in karst caves. Analysis, based on six months research, showed that statistically a significant difference between sinter and clay pools habitats and hygropetric habitats exist. This result is implying that cave habitats, holding very small quantities of water, are much more diverse than previously thought.

The recorded taxon richness of protists in the Veternica cave shows a high number of taxa, especially considering the small number of samples and prospected habitats. Thus, taxon richness of protists in caves could be much richer in comparison with diversity of cave animals. As protists are very scarcely researched in caves, future research should focus on investigating characteristics of small aquatic habitats in conditions where bat's guano is absent in order to determine its impact on protist assemblages.

Research in the Veternica cave provided valuable information about the protists in caves that are an important component of subterranean food webs supporting stunning biodiversity of subterranean animals. Thus, further effort should be given to the research that could shed light on these trophic relations.

\section{Acknowledgements}

This research was performed as a student project for the Rector's award of University of Zagreb and it was partially supported under project Implementation of the composition of aquatic fauna in evaluation of environment 119-0000000-1205 (University of Zagreb, Faculty of Science, project leader prof. dr. Biserka Primc, 2011-2012). We would like to express our gratitude to the colleagues who accompanied us for the field trips, provided us with valuable information, maps, support and advices during this research: R. Baković, P. Žvorc, J. Rubinić, S. Gottstein, P. Škuljević, I. Šimičić, M. Karlica, M. Uroić, J. Bedek, M. Lukić, S. Malić-Limari, D. Kovačić, T. Ban Ćurić and N. Fressl. Special thanks to the employees of Public Institution Nature Park Medvednica for their support. We thank Steffen Clauß from Germany for his willingness to take some SEM images of the scales of two heliozoans and Robert Baković for adaptation of Veternica cave map. This research was performed under the permission of the Croatian Ministry of Culture (Class: UP/I-612-07/11-33/0709, Ref. No.: 532-08-02-03/111-04, 15.6.2011) and Croatian Ministry of Nature and Environmental Protection (Class: UP/I-612-07/19- 48/38, Ref. No.: 517-05-1-1-19-5, 29.03.2019). 


\section{References}

Baković N (2016) Širenje lampenflore u špilji Veternici (Park prirode Medvednica) u razdoblju od 2012. do 2014. godine. Subterranea Croatica 14: 26-30.

Baković N, Siemensma FJ, Baković R, Rubinić J (2019) Testate amoebae in karst caves of the Dinaric arc (South-Eastern Europe) with a description of Centropyxis bipilata sp. nov. Acta Protozoologica 58: 201-215. https://doi.org/10.4467/16890027AP.19.018.12020

Bastian F, Alabouvette C, Saiz-Jimenez C (2009) Bacteria and free-living amoeba in the Lascaux Cave. Research in Microbiology 160:38-40. https://doi.org/10.1016/j.resmic.2008.10.001

Benk SA, Yan L, Lehmann R, Roth V-N, Schwab V F, Totsche K U, Küsel K, Gleixner G (2019) Fueling Diversity in the Subsurface: Composition and Age of Dissolved Organic Matter in the Critical Zone. Frontiers in Earth Science 7: e296. https://doi.org/10.3389/feart.2019.00296

Chibisova OI (1967) Testacea from some caves and karst reservoirs (In Russian). Zoological Zhurnal 44: 181-186.

Coppellotti O, Guidolin L (1999) "Neglected" microscopic organisms (Protozoa): possible bioindicators for karst groundwaters? In: Atti Tavola Rotonda Un importante sistema carsico dei Monti Lessini (VR): i Covoli di Velo, April 1999. Museo Civico di Storia Naturale di Verona, Dipartimento di Geografia - Universita di Padova, Commisione Speleologica Veronese, Verona-Camposilvano, 73-78.

Coppellotti Krupa O, Guidolin L (2003) Taxonomy and ecology of ciliate fauna (Protozoa, Ciliophora) from karst caves in North-East Italy. Subterranean Biology 1: 3-11.

Culver DC, Pipan T (2009) The biology of caves and other subterranean habitats, The biology of habitats series. Oxford University Press, New York, 276 pp.

Čepelak M (1978) Objašnjenja uz nacrt špilje Veternice. Speleolog 26/27: 33.

Delhez F, Chardez D (1970) Protozoaires des Grottes de Belgique. Annales de Spéléologie 25: 107-137.

Dovgal IV, Vargovitsh RS (2010) Troglobiontic suctorian and apostome ciliates (Ciliophora): an overview. Natura Montenegrina 9: 265-274.

Fernandez-Cortes A, Cuezva S, Sanchez-Moral S, Cañaveras JC, Porca E, Jurado V, MartinSanchez PM, Saiz-Jimenez C (2011) Detection of human-induced environmental disturbances in a show cave. Environmental Science and Pollution Research 18: 1037-1045. https://doi.org/10.1007/s11356-011-0513-5

Foissner W (1997) Global soil ciliate (Protozoa, Ciliophora) diversity: a probability-based approach using large sample collections from Africa, Australia and Antarctica. Biodiversity and Conservation 6: 1627-1638. https://doi.org/10.1023/A:1018378822687

Foissner W, Berger H (1996) A user-friendly guide to the ciliates (Protozoa, Ciliophora) commonly used by hydrobiologists as bioindicators in rivers, lakes, and waste waters, with notes on their ecology. Freshwater Biology 35: 375-482. https://doi. org/10.1111/j.1365-2427.1996.tb01775.x

Foissner W, Berger H, Blatterer H, Kohmann F (1995) Taxonomische und ökologische Revision der Ciliaten des Saprobiensystems - Band IV: Cyrtophorida, Oligotrichida, Hypotrichia, Colpodea. Informationsberichte des Bayerischen Landesamtes für Wasserwirtschaft, München, 540 pp. 
Foissner W, Berger H, Kohmann F (1992) Taxonomische und ökologische Revision der Ciliaten des Saprobiensystems - Band II: Peritrichia, Heterotrichida, Odontostomatida. Informationsberichte des Bayerischen Landesamtes für Wasserwirtschaft, München, 502 pp.

Foissner W, Berger H, Kohmann F (1994) Taxonomische und ökologische Revision der Ciliaten des Saprobiensystems - Band III: Hymenostomata, Prostomatida, Nassulida. Informationsberichte des Bayerischen Landesamtes für Wasserwirtschaft, München, 548 pp.

Foissner W, Blatterer H, Berger H, Kohmann F (1991) Taxonomische und ökologische Revision der Ciliaten des Saprobiensystems - Band I: Cyrtophorida, Oligotrichida, Hypotrichia, Colpodea. Informationsberichte des Bayerischen Landesamtes für Wasserwirtschaft, München, $478 \mathrm{pp}$.

Ford D, Williams P (2007) Karst Hydrogeology and Geomorphology. John Wiley \& Sons Ltd, West Sussex, 562 pp. https://doi.org/10.1002/9781118684986

Garcia-Sanchez A, Ariza C, Ubeda J, Martin-Sanchez P, Jurado V, Bastian F, Alabouvette C, Saiz-Jimenez C (2013) Free-living amoebae in sediments from the Lascaux Cave in France. International Journal of Speleology 42: 9-13. https://doi.org/10.5038/1827-806X.42.1.2

Gittleson SM, Hoover RL (1969) Cavernicolous protozoa: review of the literature and new studies of Mammoth Cave, Kentucky. Annals of Speleology 24: 737-776.

Gittleson SM, Hoover RL (1970) Protozoa of underground waters in caves. Annals of Speleology 25: 91-106.

Golemansky VG, Bonnet L (1994) Protozoa. In: Juberthie Ch, Decu V (Eds) Encyclopaedia Biospeologica, Tome I. Société de Biospéologie, Moulis-Bucarest, 23-33.

Gottstein Matočec S, Bakran-Petricioli T, Bedek J, Bukovec D, Buzjak S, Franičević M, Jalžić B, Kerovec M, Kletečki E, Kralj J, Kružić P, Kučinić M, Kuhta M, Matočec N, Ozimec R, Rađa T, Śtamol V, Ternjej I, Tvrtković N (2002) An overview of the cave and interstitial biota of Croatia. Natura Croatica 11: 1-112.

Kahl A (1930) Urtiere oder Protozoa I: Wimpertiere oder Ciliata (Infusoria). In: Dahl F (Ed.) Die Tierwelt Deutschlands. G. Fisher, Jena, 886 pp.

Kajtezović N, Rubinić J (2013) Water and research of underground habitats in protected areas - Example of protozoa research in Veternica Cave (Medvednica Nature Park, Croatia). In: Nakić Z, Rubinić J (Eds) Proceedings - $3^{\text {rd }}$ International Conference Waters in Sensitive and Protected Areas, Zagreb (Croatia), June 2013. Croatian Water Pollution Control Society, Zagreb, 150-153.

Kosakyan A, Gomaa F, Lara E, Lahr DJG (2016) Current and future perspectives on the systematics, taxonomy and nomenclature of testate amoebae. European Journal of Protistology 55: 105-117. https://doi.org/10.1016/j.ejop.2016.02.001

Lacković D, Glumac B, Asmerom Y, Stroj A (2011) Evolution of the Veternica cave (Medvednica Mountain, Croatia) drainage system: insights from the distribution and dating of cave deposits. Geologia Croatica 64: 213-221. https://doi.org/10.4154/GC.2011.18

Lahr DJG, Lara E, Mitchell EAD (2012) Time to regulate microbial eukaryote nomenclature: Microbial Eukaryote Nomenclature. Biological Journal of the Linnean Society 107: 469-476. https://doi.org/10.1111/j.1095-8312.2012.01962.x

Luca DED, Toniello V, Coppellotti O (2005) Protozoi di acque carsiche in un'area nord orientale della provincia di Treviso. Speleologica Veneta 13: 124-131. 
Matjašič J (1962) Nova jamska Folikulinida (Euciliata, Heterotricha) iz Hercegovine. Biološki Vestnik 10: 49-53. [In Slovenian with German Abstract]

Mazei YuA, Belyakova O, Trulova A, Guidolin L, Coppellotti O (2012) Testate amoebae communities from caves of some territories in European Russia and North-Eastern Italy. Protistology 7: 42-50.

Mazei YuA, Tsyganov A (2006) Freshwater testate amoebae. KMK, Moscow, 300 pp.

Moldovan OT, Kováč L, Halse S [Eds] (2018) Cave Ecology, Ecological Studies, Analysis and Synthesis, Vol. 235. Springer International Publishing, Cham, 545 pp. https://doi. org/10.1007/978-3-319-98852-8

Mulec J (2014) Human impact on underground cultural and natural heritage sites, biological parameters of monitoring and remediation actions for insensitive surfaces: Case of Slovenian show caves. Journal for Nature Conservation 22: 132-141. https://doi.org/10.1016/j. jnc.2013.10.001

Mulec J, Dietersdorfer E, Üstüntürk-Onan M, Walochnik J (2016) Acanthamoeba and other free-living amoebae in bat guano, an extreme habitat. Parasitology Research 115: 13751383. https://doi.org/10.1007/s00436-015-4871-7

Mulec J, Oarga-Mulec A, Šturm S, Tomazin R, Matos T (2017) Spacio-Temporal Distribution and Tourist Impact on Airborne Bacteria in a Cave (Škocjan Caves, Slovenia). Diversity 9(3): e28. https://doi.org/10.3390/d9030028

Ogden CG, Hedley RH (1980) An atlas of freshwater testate amoebae, Publication - British Museum (Natural History). Oxford University Press [for the] British M useum (Natural History), Oxford, 222 pp.

Page FC, Siemensma FJ (1991) Nackte Rhizopoda und Heliozoea, Protozoenfauna. Gustav Fischer Verlag, Stuttgart-New York, 297 pp.

Sigala-Regalado I, Mayen-Estrada R, Morales-Malacara J (2011) Spatial and Temporal Distribution of Protozoa at Cueva de Los Riscos, Querétaro, México. Journal of Cave and Karst Studies 73: 55-62. https://doi.org/10.4311/jcks2009mb121

Simon K, Pipan T, Culver D (2007) A conceptual model of the flow and distribution of organic carbon in caves. Journal of Cave and Karst Studies 69: 279-284.

Tsyganov AN, Babeshko KV, Mazei YA (2016) A guide to testate amoebae with the keys to genera. Publishing house PGU, Penza, 131 pp.

Vandel A (1965) Biospeleology: the biology of cavernicolous animals. Pergamon Press, Oxford, 552 pp. https://doi.org/10.1016/B978-0-08-010242-9.50027-X

Walochnik J, Mulec J (2009) Free-living Amoebae in Carbonate Precipitating Microhabitats of Karst Caves and a New Vahlkampfiid Amoeba, Allovahlkampfia spelaea gen. nov., sp. nov. Acta Protozoologica 48: 25-33.

Wilhartitz IC, Kirschner AKT, Brussaard CPD, Fischer UR, Wieltschnig C, Stadler H, Farnleitner AH (2013) Dynamics of natural prokaryotes, viruses, and heterotrophic nanoflagellates in alpine karstic groundwater. MicrobiologyOpen 2: 633-643. https://doi. org/10.1002/mbo3.98 